\title{
Hexaplaric Recension and Hexaplaric Readings in 1 Samuel
}

\section{Aejmelaeus, Anneli}

Vandenhoeck \& Ruprecht

2021

Aejmelaeus , A 2021, Hexaplaric Recension and Hexaplaric Readings in 1 Samuel . in D Candido , J Alfaro \& K De Troyer (eds) , On Hexaplaric and Lucianic Readings and Recensions . De Septuaginta Investigationes, no. 014 , Vandenhoeck \& Ruprecht , Göttingen , pp. 13-37 . https://doi.org/10.13109/9783666522130.13

http://hdl.handle.net/10138/327997

https://doi.org/10.13109/9783666522130.13

unspecified

acceptedVersion

Downloaded from Helda, University of Helsinki institutional repository.

This is an electronic reprint of the original article.

This reprint may differ from the original in pagination and typographic detail.

Please cite the original version. 


\section{Hexaplaric Recension and Hexaplaric Readings in 1 Samuel}

Anneli Aejmelaeus

\section{Introduction}

The Hexaplaric recension is the most well-known of the Christian recensions of the Septuagint. Nevertheless, there are still many puzzles around it. I am approaching the topic from the angle of textual transmission, and in particular, from the angle of the textual transmission of one biblical book, so that I am not primarily interested in taking part in the big debates concerning the work of Origen. He was no doubt the originator of the text-historical phenomenon of the Hexaplaric recension and Hexaplaric readings that can be observed in the textual transmission, although we do not know for sure what his personal role was and how he proceeded fulfilling his task. What concerns me is the after-effect that can be observed in the textual evidence offered by the various manuscripts available to us and how to explain it.

I need not start by describing Origen's great text-critical endeavour, the Hexapla and its six columns that were meant to facilitate the comparison between the Septuagint and the Hebrew text - the sacred texts of the Church and the Synagogue in the third century CE - a huge, ambitious endeavour in which the three later Greek versions (Aquila, Symmachus, and Theodotion) were employed to ease the access to the Hebrew text and to help Origen "heal" the text of the Septuagint. ${ }^{1}$

Instead of putting an end to textual variation, Origen's great text-critical work eventually opened the gates to a flood of approximations of the Greek text to the Hebrew, the most commonly mentioned of these being the complementation of elements of the Hebrew text not present in the Old Greek, marking these complementations with an asterisk as well as marking plusses of the Greek text that had no correspondence in the Hebrew text with an obelus, the change of word-order to conform to the Hebrew text, and the correction of proper names according to the Hebrew. Examples of these features can be seen all over the critical apparatus of any Septuagint book (that has a Hebrew Vorlage), as they have spread to a varying number of manuscripts. ${ }^{2}$

\footnotetext{
${ }^{1}$ See the fundamental study of Bernhard Neuschäfer, Origenes als Philologe, I-II, Schweizeriche Beiträge zur Altertumswissenschaft 18/1-2 (Basel: Friedrich Reinhardt Verlag,1987); and its reception by Joachim Schaper, "The Origin and Purpose of the Fifth Column of the Hexapla," in Origen's Hexapla and Fragments: Papers Presented at the Rich Seminar on the Hexapla, Oxford Centre for Hebrew and Jewish Studies $25^{\text {th }}$ July - $3^{\text {rd }}$ August 1994, ed. Alison Salvesen, TSAJ 58 (Tübingen: Mohr Siebeck, 1998), 3-15. Origen's work and impact on the textual history of the Septuagint are discussed, for instance, by Sidney Jellicoe, The Septuagint and Modern Study (Oxford: Clarendon, 1968) 100-33; Natalio Fernández Marcos, The Septuagint in Context: Introduction to the Greek Versions of the Bible (Boston/Leiden: Brill, 2001), 204-20; Alison Salvesen, "A Convergence of the Ways? The Judaizing of Christian Scripture by Origen and Jerome," in The Ways that Never Parted: Jews and Christians in Late Antiquity and the Early Middle Ages, ed. Adam H. Becker and Annette Yoshiko Reed, TSAJ 95 (Tübingen: Mohr Siebeck, 2003), $233-58$.

${ }^{2}$ For the text-historical disaster caused by Origen, see Salvesen, “A Convergence of the Ways?", 242-6; see also Samuel R. Driver, Notes on the Hebrew Text and the Topography of the Books of Samuel (2 ${ }^{\text {nd }}$ edition, revised and enlarged; Oxford: Clarendon, 1913), xliii: “Origen, no doubt, freed the text of the LXX from many minor faults; but in
} 


\section{Early Comparison of the Septuagint with the Hebrew Text and Approximation to It}

Origen was, however, not the first one to compare the Greek text with the Hebrew and to take measures accordingly. The attitude of both Jews and Christians to the traditional Septuagint was curiously ambivalent. The Septuagint was the first Bible of the Christians and was in that sense authoritative. At least among the Diaspora Jews, the Septuagint - above all the Greek Torah - was also considered to be Scripture. At the same time, the Hebrew text - the contemporary Hebrew text at hand - was considered to be a valid criterion for revisions to be made on the Greek text.

What were the factors that gave rise to such early revisional activity? Until the time of Origen, the Septuagint had already had a long history of copying, which always produces errors as we know. One even more important factor that triggered the activity of the revisers was the Hebrew text itself, as many parts of it were still under editorial activity at least until the turn of the era. The later the Hebrew text of a certain book continued to be edited, the more there were differences between the Vorlage of the Septuagint and the Hebrew text that was used for comparison, and accordingly, the more revisional activity can be expected to have happened on the Greek text already during the preHexaplaric period - as well as later. ${ }^{3}$

The Books of Samuel and Kings are good examples for this. Previous generations of textual critics tended to think that - except for scribal errors - all the differences that called for revision were caused by the translators, either through erroneous or free translation or paraphrasing. ${ }^{4}$ In the present post-Qumran era, it has become clear to most scholars that the Vorlage time and again differed substantially from the proto-MT of the revisers as well as the later MT that we use for comparison. Nevertheless, in the historical books we do also find numerous cases in which erroneous translation was the factor that triggered revision. The two kinds of differences - those caused by the editors of the Hebrew text and by the Greek translators - do not exclude each other. In Samuel and Kings both kinds are well represented. No wonder then that these books have such an eventful textual history.

\section{Origen's Understanding of the Textual History of the Septuagint by His Time}

\footnotetext{
the main his work tended to obliterate the most original and distinctive features of the Version. To discover the Hebrew text used by the translators we must recover, as far as possible, the text of the Version as it left the translators' hands; and Origen's labours, instead of facilitating, rather impeded this process."

${ }^{3}$ See my article "The Origins of the Kaige Revision," in Scriptures in the Making: Texts and Their Transmission in Late Second Temple Judaism, ed. Raimo Hakola, Paavo Huotari and Jessi Orpana, CBET (Leuven: Peeters, 2020), forthcoming.

${ }^{4}$ For instance, John William Wevers, Notes on the Greek Text of Deuteronomy, SCS 39 (Atlanta, GA: Scholars Press, 1995), xxii: "One should not automatically presuppose a different parent text when differences between the Greek and the Hebrew obtain; rather one should first seek for and pursue other explanations. It is only through such details that a picture of the attitudes, the theological prejudices, as well as of the cultural environment of these Jewish translators can emerge." By contrast, it is often the attitudes and prejudices of the editors of the Hebrew text that emerge through the differences between the Hebrew and the Greek text.
} 
As for Origen, he naturally had no idea about the development of the Hebrew text. When he compared the Septuagint manuscripts that were available to him with the Hebrew text, he took it for granted that this very same Hebrew text had been the Vorlage of the Septuagint, and he followed the principle of regarding the reading in agreement with this Hebrew text as the original wording of the Septuagint. In the case of divergences, he gathered that they must have been caused either by careless copying or by the arrogance of some copyists to change the text.

It is, however, seldom considered at all that Origen had several Septuagint manuscripts and that he was troubled not only by the differences between the Hebrew and the Greek texts, but also by the divergences between the Greek copies. ${ }^{5}$ Consequently, he had a twofold task (1) to "heal" the text of the Septuagint from all corruption and (2) to clarify for those Christians who engaged in the debates with the Jews what were the differences between the Hebrew and the Greek Scriptures.

In what follows, I am going to give examples for different aspects of Origen's text-critical work and of the subsequent influence of the Hexapla. I shall start with Origen's own statement concerning his text-critical work and then proceed by examples of the different kinds of readings encountered by Origen and at the end discuss in brief Hexaplaric influence after Origen.

\section{Origen's Statement concerning His Text-Critical Work}

In the famous passage in his Commentary on Matthew (15.14), Origen describes the procedure of comparing manuscripts and deciding between readings:

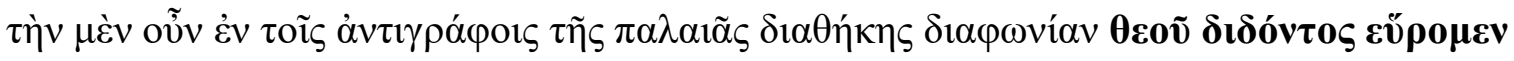

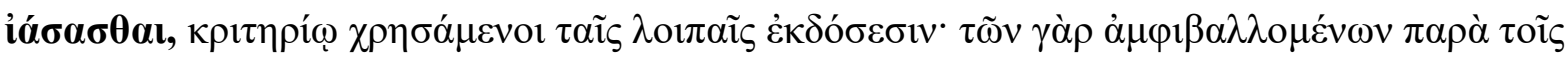

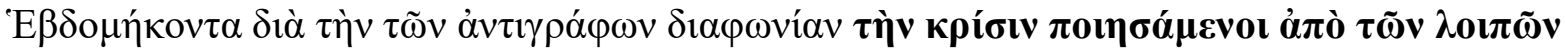

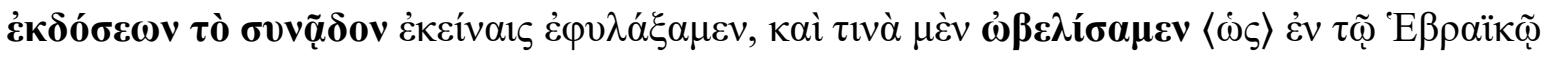

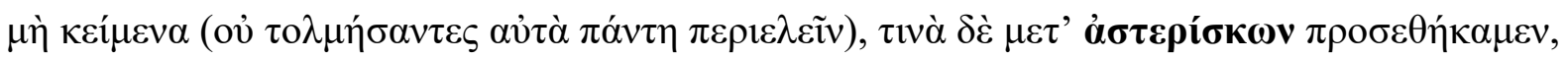

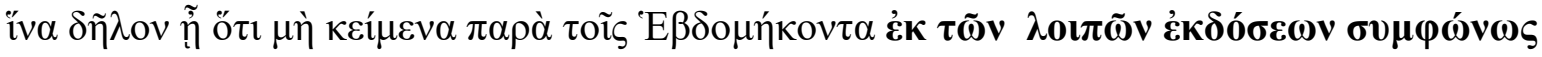

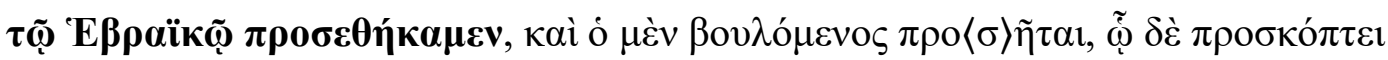

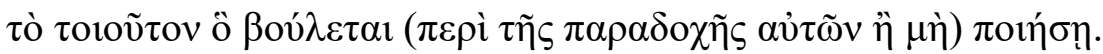

For the lack of consistency in the manuscripts of the Old Testament, we have with God's help found a cure, while we use the other versions as a yardstick; what was dubious in the Septuagint on account of manuscripts lacking consistency, we judge this from the other versions, and retain what is in harmony with them. Moreover, such places that are not in the Hebrew (we did not dare to erase them completely), we mark some with an obelus. Other places we mark with an asterisk to make clear that what we added from the other versions in harmony with the Hebrew is not found in the

\footnotetext{
${ }^{5}$ See Frederick Field's Prolegomena to Origenis Hexaplorum quae supersunt, sive veterum interpretum graecorum in totum Vetus Testamentum fragmenta, Translated and annotated by Gérard J. Norton O.P., with the collaboration of Carmen Hardin, CahRB 62 (Paris: J. Gabalda, 2005), 91-3 (orig. xlvi-xlviii), 99-100 (orig. li-lii), 113-5 (orig. 1x-xli).
} 
Septuagint. Whoever wants to can accept these variants, but to whom such a thing is objectionable, he can accept or refuse as he wishes. ${ }^{6}$

While commenting on the Gospel of Matthew, Origen takes up the theme of possible textual changes in Matthew and compares with it the situation in the Old Testament, where he can solve textual problems by comparison with the Hebrew text. This is indeed the difference between the New Testament and the Septuagint in textual criticism: the Hebrew text always plays a role in the textual criticism of the Septuagint - although the matter is a bit more complicated than presupposed by Origen.

As a matter of fact, Origen does not say that he compared the diverging Greek manuscripts directly with the Hebrew text, but with the three later versions of Aquila, Symmachus and Theodotion, and he chose the reading that was "in harmony" ( $\tau$ ò $\sigma v v a \tilde{a} \delta o v)$ with them. The Three provided an easy access to the Hebrew, which he obviously was not completely fluent with. ${ }^{7}$ In addition, he mentions the use of obelus to mark plusses of the Greek text, which he did not want to excise, and asterisk to mark the filling in of minuses of the Greek text in comparison with the Hebrew, which happened with the help of the Three, mainly Theodotion. ${ }^{8}$

It seems obvious to me that Origen discusses in the passage at hand different kinds of variant readings, not only the quantitative differences between the Septuagint and the Hebrew text of his time (the so-called plusses and minuses), although the passage has often been interpreted as referring to those only. How he speaks about the diverging copies - "the lack of consistency in the manuscripts of the Old Testament" - would be a curious way to refer to the same variants that he discusses on the following lines when he mentions the use of asterisk and obelus. Rather, the firstmentioned divergences are those between different manuscripts of the Septuagint, the Scripture of the Church, and the criterion for deciding between them was what is "in harmony" ( $\tau$ ò $\sigma v v \tilde{\alpha} \delta$ ov $)$ with the Hebrew text as reflected by the Three - not identical, but "in harmony." This is not what he did with the plusses and minuses. Deciding between variants found in copies of the Septuagint is what Origen refers to as "healing" the text. ${ }^{9}$ The readings that resulted from the "healing" procedure were not marked in any way.

There has been a long debate about what Origen actually refers to in the quoted passage, whether he is explaining the construction of the fifth column of the Hexapla (the Septuagint column) or

\footnotetext{
${ }^{6}$ For the interpretation of Origen's Comm. Matth. 15.14 (as well as the other ancient texts on Origen's textcritical work), see Neuschäfer, Origenes als Philologe, 86-94. See also Schaper, "The Origin and Purpose of the Fifth Column of the Hexapla," 6-9. The Greek texts with translations are found in Fernández Marcos, The Septuagint in Context, 204-10.

${ }^{7}$ Consider the estimations by Bernhard Neuschäfer, Origenes als Philologe, I-II, Schweizeriche Beiträge zur Altertumswissenschaft 18/1-2 (Basel: Friedrich Reinhardt Verlag,1987), 95: “... dass die Kenntnis des Hebräischen, über die Origenes verfügte, im Vergleich mit anderen Kirchenvätern zwar erstaunlich, an objektiven Massstäben gemessen aber begrenzt gewesen sein muss"; as well as by Alison Salvesen, “A Convergence of the Ways?”, 240, n. 22: "Origen's own knowledge of Hebrew was very limited and depended heavily upon the renderings of the Three. His proficiency fell very far short of Jerome's."

${ }^{8}$ The general assumption that Origen mainly used Theodotion (see for instance, Jellicoe, The Septuagint and Modern Study, 109), placed in the sixth column next to the Septuagint, to complement the text of the Septuagint is confirmed by numerous Hexaplaric readings that happen to correspond to occasionally preserved readings of Theodotion.

${ }^{9}$ This view is supported by Neuschäfer, Origenes als Philologe, 94. See also Salvesen, “A Convergence of the Ways?”, 240 .
} 
speaking of a recension of the Septuagint that he prepared separately from the Hexapla. ${ }^{10}$ As for the textual transmission that was influenced by Origen's work, it does really not make much difference whether this influence was mediated through the Hexapla or another edition of the text outside of it. However, in light of the textual transmission of 1 Samuel - which is my task here - if one considers what Origen says about the differences between the Greek copies, it seems impossible that Origen could have constructed his fifth column without precisely this kind of text-critical work. How could he otherwise have decided which words to copy into his fifth column, when his manuscripts differed from each other? He could not include different readings of the Septuagint in his Hexapla. ${ }^{11}$ The only criterion he could possibly use was agreement with the Hebrew text, and this could easily be evaluated by the information in the Hexapla. This is how Origen tried to eliminate scribal changes as well as copying errors, but at times he also happened to eliminate the original, if one of the alternatives happened to be a pre-Hexaplaric approximation to the Hebrew text.

Let us look at some examples to see how Origen's work is reflected in the textual transmission of 1 Samuel. $^{12}$

\section{"Healing the Text"}

\section{Qualitative variants}

One of my most important discoveries in the textual history of 1 Samuel is that the early preHexaplaric revisional activity, known as kaige-revision, ${ }^{13}$ has left its marks not only in the so-called

\footnotetext{
${ }^{10}$ For the debate whether or not Origen used the Aristarchian signs in the fifth column of the Hexapla or in some other edition of his, see Fernández Marcos, The Septuagint in Context, 213-5; for the former view, for instance, Ilmari Soisalon-Soininen, Der Charakter der asterisierten Zusätze in der Septuaginta, AASF B 114 (Helsinki: Suomalainen tiedeakatemia, 1959), 197; Sebastian P. Brock, The Recensions of the Septuagint Version of 1 Samuel (Ph.D.

dissertation, Oxford 1966), Quaderni di Henoch 9 (with a Foreword by Natalio Fernández Marcos; Torino: Silvio Zamorani, 1996), 170; Schaper, "The Origin and Purpose of the Fifth Column of the Hexapla," 9, 15; and Salvesen, "A Convergence of the Ways?”; for the latter view, for instance, Bernhard Neuschäfer, Origenes als Philologe, 96-8; and more recently Anna Kharanauli, "Origen and Lucian in the Light of Ancient Editorial Techniques," in From Scribal Error to Rewriting: How Ancient Texts Could and Could Not Be Changed, ed. Anneli Aejmelaeus, Drew Longacre \& Natia Mirotadze, DSI 12 (Göttingen: Vandenhoeck \& Ruprecht, 2020), 15-52.

${ }^{11}$ In addition, it is difficult to ascribe the "healing" of the text and the dealing with plusses and minuses discussed in close context to different phases of text-critical work (see also Schaper, "The Origin and Purpose of the Fifth Column of the Hexapla," 9).

12 The manuscripts available for the First Book of Samuel, with their tentative groupings, are the following (with those only partially preserved in parentheses): B A V (M) (842) (845) (846) (867); $O=247-376 ; L=19-82-93-108-127 ; C I=$ 98-(243)-379-731; $C I I=46-52-236-242-313-328-530 ; a=119-527-799 ; b=121-509 ; d=44-68-74-106-107-120-122-$ 125-134-(370)-610; $f=56-246 ; s=64-92-130-314-381-488-489-(762) ; 295571158244245318(342) 460554707$. As for the group sigla, $O$ stands for the Hexaplaric, $L$ for the Lucianic, $C$ for Catena manuscripts. See Offizielles Verzeichnis der Rahlfs-Sigeln, Stand: Dezember 2012, ed. Septuaginta-Unternehmen der Akademie der Wissenschaften zu Göttingen (https://rep.adw-goe.de/handle/11858/00-001S-0000-0022-A30C-8).

${ }^{13}$ Dominique Barthélemy (Les devanciers d'Aquila, VTSup X [Leiden: Brill, 1963]) relied on Henry St. John Thackeray ("The Greek Translation of the Four Books of Kings," JTS 8 [1907]: 262-78) in his division of SamuelKings to sections with different translation styles. He defined the two so called kaige sections as 2 Samuel 11:2 - 1 Kings 2:11 and 1 Kings $22-2$ Kings 25. The beginning of the first kaige section at 2 Sam 11:2 has been challenged recently and placed at 2 Sam 10:6 by Raimund Wirth, "Dealing with Tenses in the Kaige Section of Samuel," in The Legacy of Barthélemy: 50 Years after Les Devanciers d'Aquila, ed. A. Aejmelaeus \& T. Kauhanen, DSI 9 (Göttingen: Vandenhoeck \& Ruprecht, 2017), 185-97.
} 
kaige-sections in Samuel-Kings but also in what was believed to be non-kaige-sections, ${ }^{14}$ and this insight has important repercussions on my understanding of the work of Origen. These kaige-type readings are found sporadically in 1 Samuel and especially in the B text represented by Codex Vaticanus (B) and its satellites 121-509 (= b; Aeth), and these readings are followed by a small number of witnesses, most prominent among them the manuscripts that Alfred Rahlfs already recognized as Hexaplaric, namely Codex Alexandrinus (A) and the minuscules 247-376 (=O; Arm). These manuscripts are the closest we come to the fifth column of the Hexapla - or should we say: the Septuagint text "healed" by Origen. ${ }^{15}$

Several scholars have made the observation that Origen's basic Septuagint text was close to Vaticanus. ${ }^{16}$ I would like to modify this statement by saying that the B text was represented among the various manuscripts used by Origen: he followed it in significant readings but could also decide against it. The B text is an Alexandrian text-type, and it is thus natural to think that it was known to Origen. Of course, this presupposes that the text-type is older than the manuscripts that represent it. If it was developed in Alexandria during the late $2^{\text {nd }}$ century CE, when the Christian school of Alexandria rose to fame, this explains how it was available to Origen. ${ }^{17}$

My first example of a qualitative variant adopted by Origen into his Septuagint is from 1 Samuel 30: ${ }^{18}$ When chasing after the Amalekites, David had to divide his troops and leave 200 men behind. Now in v. 21, he is returning to those 200.

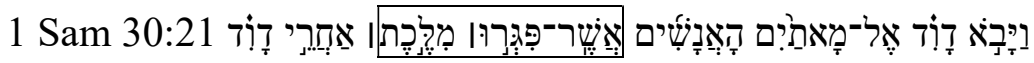

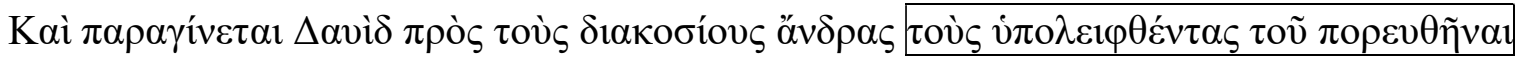

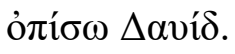

$\dot{v} \pi \mathrm{o} \lambda \varepsilon 1 \varphi \theta \varepsilon \dot{\varepsilon} \tau \alpha \varsigma] \alpha \pi \mathrm{o} \lambda \varepsilon 1 \varphi \theta \varepsilon v \tau \alpha \varsigma L^{-93} ; \varepsilon \kappa \lambda v \theta \varepsilon v \tau \alpha \varsigma$ B A $O b \mathrm{Ra}=\mathrm{MT}$ |

\footnotetext{
${ }^{14}$ See Anneli Aejmelaeus, "Kaige Readings in a Non-Kaige Section in 1 Samuel," in The Legacy of Barthélemy: 50 Years after Les Devanciers d'Aquila, ed. Anneli Aejmelaeus and Tuukka Kauhanen, DSI 9 (Göttingen: Vandenhoeck \& Ruprecht, 2017), 169-184; and "Does God Regret? A Theological Problem that Concerned the Kaige Revisers," in The Legacy of Barthélemy: 50 Years after Les Devanciers d'Aquila, ed. Anneli Aejmelaeus and Tuukka Kauhanen, DSI 9 (Göttingen: Vandenhoeck \& Ruprecht, 2017), 41-53.

${ }^{15}$ Bo Johnson, Die hexaplarische Rezension des 1. Samuelbuches der Septuaginta, Studia Theologica Lundensia 22 (Lund: Gleerup, 1963), aims at defining the Hexaplaric text in 1 Samuel, but does not recognize this source of qualitative variants in Origen's text (esp. p. 46-53); the main problem in his study is that he regards B practically as the original text of the Septuagint to which he compares all other manuscripts.

${ }^{16}$ See already Henry Barclay Swete, An Introduction to the Old Testament in Greek (2 ${ }^{\text {nd }}$ edition; Cambridge: University Press, 1914 [originally published 1900]), 487, and Alfred Rahlfs, Septuaginta-Studien I-III. 2. Auflage, Vermehrt um einen unveröffentlichten Aufsatz und eine Bibliographie mit einem Nachruf von Walter Bauer (Göttingen: Vandenhoeck \& Ruprecht, 1965), 101 [Septuaginta-Studien I was originally published in 1904]; Rahlfs suggests that B was "cum grano salis die Vorlage des Origenes." See also Brock, The Recensions of the Septuagint Version of 1 Samuel, 170.

${ }^{17}$ The B text seems to have been the earliest Christian recension of the Biblical text; see my article "Textual History of the Septuagint and the Principles of Critical Editing," in The Text of the Hebrew Bible and Its Editions: Studies in Celebration of the Fifth Centennial of the Complutensian Polyglot, ed. by Andrés Piquer Otero \& Pablo Torijano Morales, Supplements to the Textual History of the Bible 1 (Leiden/Boston: Brill, 2016), 160-79 (esp. 175).

${ }^{18}$ The following examples will be given according to the critical text of the forthcoming edition, whereas readings of Rahlfs's edition are marked by Ra. The information given on the readings represented by various Greek manuscripts includes just what is essential for the discussion in this paper. For the sake of clarity, minor variants as well as daughter versions and Patristic quotations have been excluded. As usual, the list of manuscripts for the majority reading is not given in the apparatus but can be derived from the list of all witnesses by deducting the manuscripts representing variant readings. See for instance the following footnote.
} 
$\pi \mathrm{o} \rho \varepsilon v \theta \tilde{\eta} v \alpha 1] \pi \mathrm{o} \varepsilon \varepsilon v \varepsilon \sigma \theta \alpha \mathrm{l}$ B A $a b 64 \cdot 342460$ |

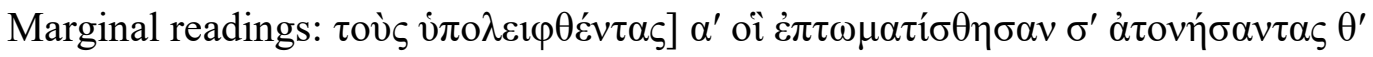

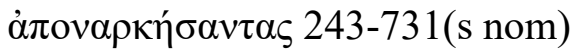

The Hebrew text refers to these men as those "who were too exhausted to follow David," using the rare verb פגר pi. 'to be exhausted/faint,' which occurs only here and earlier in v. 10 of the same chapter. The translator obviously did not know the word and translated "who were left behind."19

This is one of those cases where the B text offers an early approximation ( $\dot{\varepsilon} \kappa \lambda v \theta \varepsilon \dot{\varepsilon} v \tau \alpha \varsigma)$, using the passive voice of $\dot{\varepsilon} \kappa \lambda \hat{v} \omega$ with the meaning 'to be faint,' which is clearly closer to the meaning of the Hebrew verb. This reading is found in two groups of witnesses: the B text $(\mathrm{B} b)$ and the Hexaplaric text (A $O$ ), presumably the text of Origen's fifth column. ${ }^{20}$ This is also the reading found in Rahlfs's edition, because he based his text mainly on B and A. However, if this were the original reading, it would be impossible to explain where the majority reading or the Lucianic variant came from.

Luckily enough, we know in this case also the readings of the Three who all go different ways. Aquila uses the verb $\pi \tau \omega \mu \alpha \tau i \zeta \omega$ pass. 'to fall' or 'to be ready to fall' (often used in reference to epilepsy!), formulating a relative clause as in the Hebrew. Symmachus and Theodotion have a

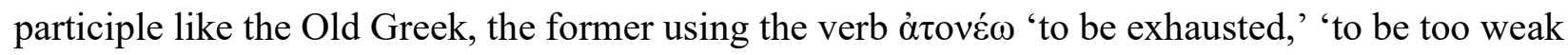
(to do something),' and the latter à ${ }^{\prime}$

Presuming that our information on the Three is correct, it seems clear that the variant $\dot{\varepsilon} \kappa \lambda v \theta \varepsilon \dot{\varepsilon} \tau \tau \alpha \varsigma$ was not adopted by Origen from the Three but rather from one of the Septuagint manuscripts that he was using, more precisely, an early exemplar of the B text. He must have known also the Old Greek

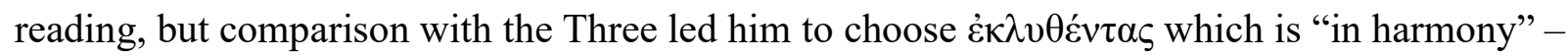
although not identical! - with the different equivalents found in the Three and thus also in harmony with the Hebrew text. ${ }^{21}$

It is interesting to compare the other case with the same difficult Hebrew word in v. 10, where the weariness of the men was mentioned first.

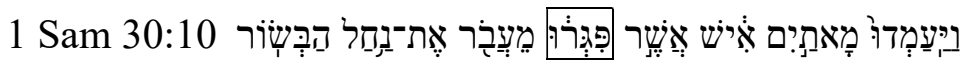

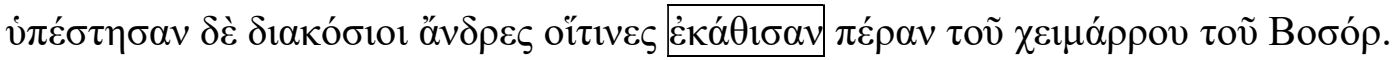

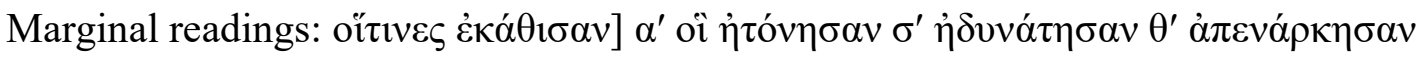

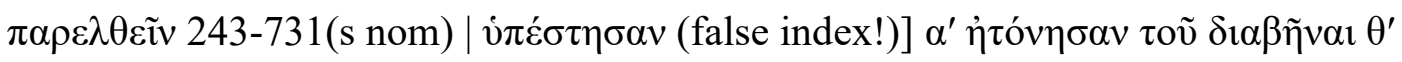

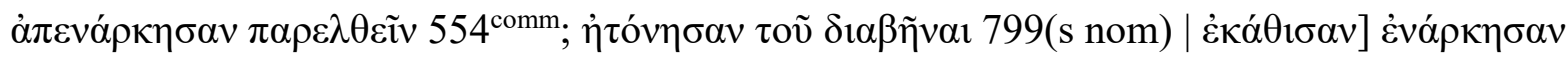
$\mathrm{M}^{\mathrm{mg}}$ (s nom) |
\end{abstract}

\footnotetext{
${ }^{19}$ The critical text follows the reading vं $\pi 0 \lambda \varepsilon i \varphi \theta \varepsilon \dot{v} \tau \alpha \varsigma$ represented in the majority of witnesses: V M 93 CI CII a $d^{(-370)}$ fs 295571158245318342460554707.

${ }^{20}$ Brock, The Recensions of the Septuagint Version of 1 Samuel, 170, is sceptical about the nature of the manuscripts A 247-376, concluding that they are related to the B text but not based on the fifth column of the Hexapla.

${ }^{21}$ The hypothetical possibility of pre-Origenic approximations among the texts used by Origen - however, without concrete evidence - has been suggested by a few scholars: Soisalon-Soininen, Der Charakter der asterisierten Zusätze, 29, 190; Brock, The Recensions of the Septuagint Version of 1 Samuel, 172; Neuschäfer, Origenes als Philologe, 99.
} 


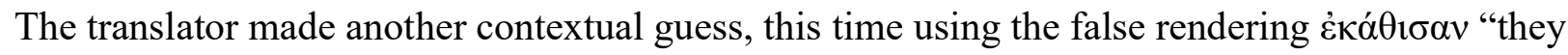

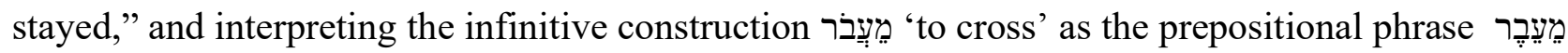
'beyond,' thus rephrasing the Hebrew "too exhausted to cross the brook" as "stayed on the other side of the brook." The story does not suffer much from this contextual guess, but in fact, it is a false rendering.

Again, the renderings of the Three are preserved in a few different notes, Aquila using this time the

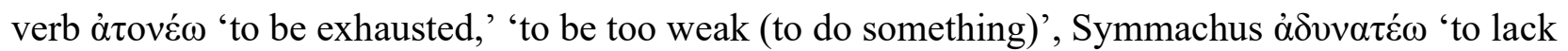

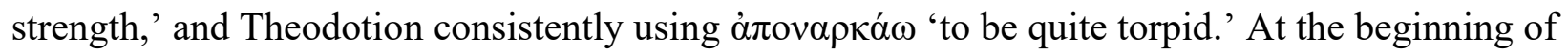
the marginal note of the catena manuscripts 243-731, the relative pronoun is mentioned just once, and similarly at the end, the infinitive $\pi \alpha \rho \varepsilon \lambda \theta \varepsilon \tilde{v} v$ 'to cross' correcting the second element, whereas $\tau$ 七õ $\delta \iota \alpha \tilde{\eta} v \alpha \iota$ is found in another note for Aquila (554).

How did Origen react to this case? Curiously enough, there is no revisional variant preserved for $\dot{\varepsilon} \kappa \alpha \dot{\theta} \theta \imath \sigma \alpha \nu$ in the manuscripts available to us. Origen probably did not have any variants to choose

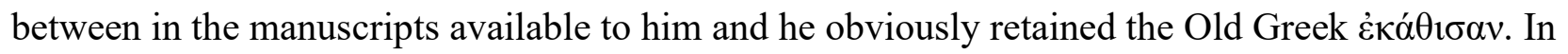
the Hexapla, he had the renderings of the Three that agree with the Hebrew text, but because of the unanimity of his Septuagint manuscripts, there was nothing "to be healed" in the text of the Church this time. ${ }^{22}$

\section{Word Order}

Adjusting the word order to the Hebrew text is another one of Origen's "healing" actions. Examples of this kind are numerous.

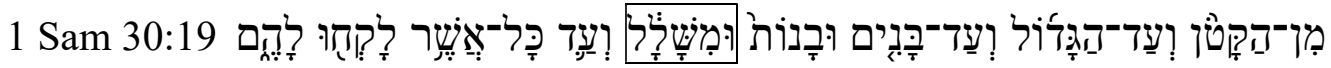

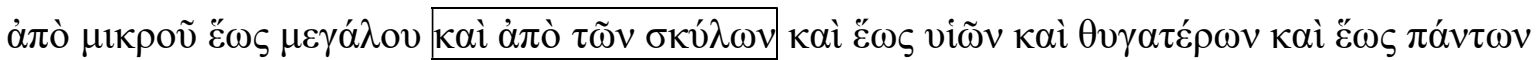

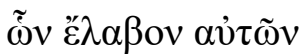

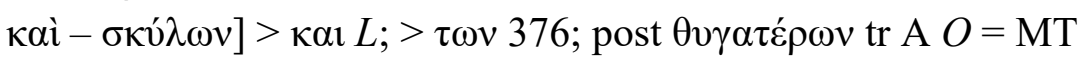

The passage lists the prisoners and the booty returned from the Amalekites. The relative order of "from the booty" and "to sons and daughters" is different in the two texts. Both orders are in a way logical, and it is difficult to decide which one should be considered more original. ${ }^{23}$ The change according to the Hebrew text occurs only in the Hexaplaric manuscripts (A $O$ ). The change of order was probably a practical necessity when compiling the Hexapla. Otherwise, it would have been

\footnotetext{
${ }^{22}$ Origen obviously did not go so far in his consultation of the Hebrew text that he would have assimilated the two cases containing one and the same Hebrew verb. Cf. Soisalon-Soininen, Der Charakter der asterisierten Zusätze, 195, when describing Origen's manner of working: “...direct nach dem Hebräischen hat er kaum korrigiert.” Similarly, Salvesen, "A Convergence of the Ways?", 241.

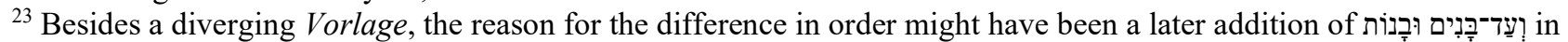
the proto-MT in order to clarify the expression "from small to great"; this would explain the imbalance in the "from to" structure. Subsequently, the plus would have been added as a marginal note to the Greek text, from where it later ended up in a different location compared to the MT.
} 
difficult to place the Greek words into the column opposite to the Hebrew text. ${ }^{24}$ Examples of this kind suggest that A $O$ are the manuscripts that best of all transmit the text of the fifth column.

In another example, the change of word order already happened in the B text, which is followed by the Hexaplaric text and just a few other manuscripts.

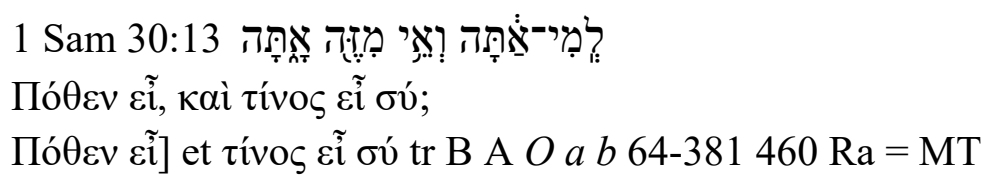

Here we can see the same pattern as above: from diverging readings Origen chose the one in harmony with the Hebrew text. ${ }^{25}$ The corrected word order was found in the B text and spread from there to a few further manuscripts. Again, A $O$ seem to witness the text of the fifth column.

\section{Proper Names}

Proper names are an area where Origen seems to have proceeded fairly independently, as far as spelling is concerned. ${ }^{26}$ Differences in the spelling of less well-known names are extremely numerous in the manuscripts. Below are a few examples.

Ziklag is a fairly well-known place-name, but there is still variation even within one manuscript and in one verse with several occurrences of the name.

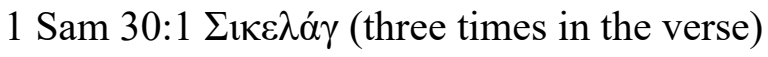

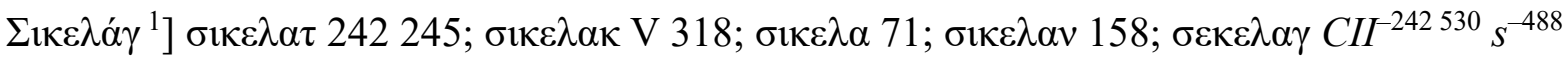

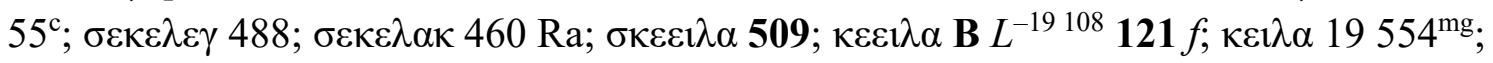
$\kappa \varepsilon 1 \lambda \alpha \gamma 108 ; \kappa \varepsilon 1 \lambda \alpha \kappa 342$

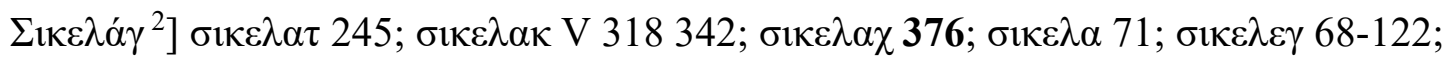

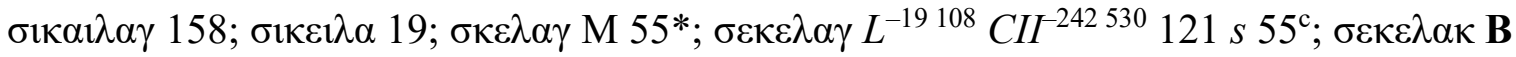

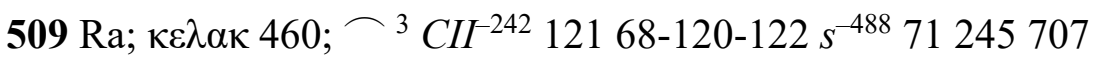

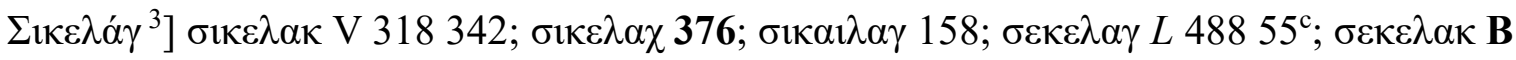
$509460 \mathrm{Ra}$

In the first case, there is also a major variant: the B text and the Lucianic text (followed by $f$ [= 56246]) refer to another town. It is a complicated case involving other variants, ${ }^{27}$ but this time Origen does not follow the B text because it is not in harmony with the Hebrew text. In all three cases, the form in the lemma that accords with the Hebrew name is found in the Hexaplaric manuscripts A

\footnotetext{
${ }^{24}$ See Field's Prolegomena, 1xi (trans. 114).

${ }^{25}$ It deserves to be noted that the personal pronoun of the second person singular is not repeated as it is in the Hebrew text, although the word-order is corrected.

${ }^{26}$ See Field's Prolegomena, 1x-1xi (trans. 113-114).

${ }^{27}$ I have dealt with 1 Sam 30:1 and its context in "David's Return to Ziklag: A Problem of Textual History in 1 Sam 30:1," in XII Congress of the International Organization for Septuagint and Cognate Studies, Leiden 2004, ed. Melvin Peters, SCS 54 (Leiden/Boston: Brill, 2006), 95-104. See also Anneli Aejmelaeus, "The Lucianic Text of 1 Samuel: A Revised and Augmented Edition of the Old Greek," in the present volume.
} 
and 247 (with minor differences in 376) and the majority of manuscripts. In the case of Ziklag, Origen in fact seems to have restored the original form of the name in the Septuagint.

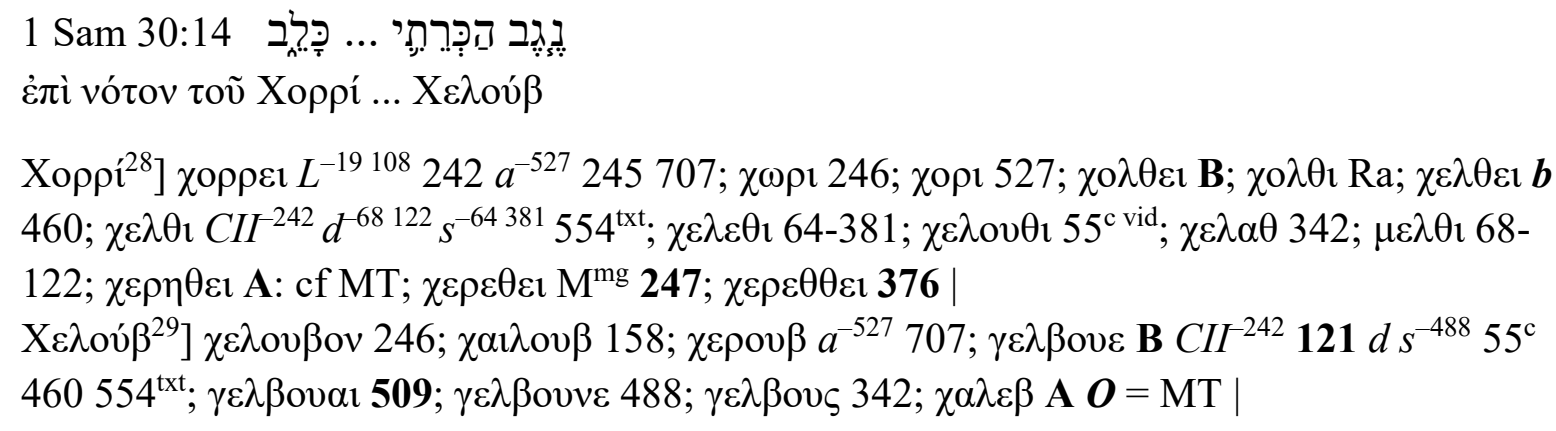

Later in the same chapter, we can see variation in two less well-known names. The Hexaplaric manuscripts (A and $O[=247-376]$ ) are the only ones that come even close to the Hebrew names, witnessing to Origen's "healing" procedure, whereas the manuscripts of the B text show different forms of a totally different name. The original form of the first name in the Septuagint is either due to a different Vorlage or a misreading by the translator.

\section{Plusses and Minuses}

\section{Plusses of the Septuagint}

Let us take an example of the plusses of the Septuagint. In the first chapter of 1 Samuel, the Greek text of Hannah's story contains several details that are not present in the Hebrew text.

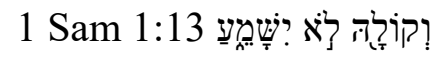

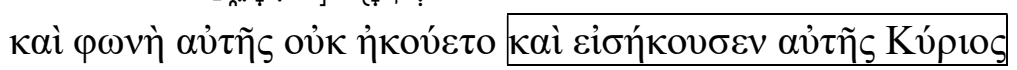

$\kappa \alpha i^{2}-$ Kúptos] > B A O bf $55245707^{\text {txt }} \mathrm{Ra}=\mathrm{MT}$

At 1 Sam 1:13, the MT does not contain the sentence "and the Lord heard her," which is part of the Old Greek, but was omitted by the B text, followed by the Hexaplaric manuscripts A $O$ and five other minuscules. ${ }^{30}$ Consequently, it is not present in the edition of Rahlfs. This omission is a feature of the early revision, made according to the proto-MT, which had possibly deleted the sentence out of ideological reasons. ${ }^{31}$ Origen must have encountered the sentence in some of his manuscripts - it is preserved until today in about fifty mss - but since there was a divergence between the Septuagint manuscripts, Origen used the Three as the criterion and omitted the sentence. According to his reasoning, it could not be considered as part of the Old Greek. If the manuscripts had been unanimous, the sentence would have stayed in place under an obelus.

\footnotetext{
${ }^{28} \mathrm{M}^{\mathrm{txt}} \mathrm{V} 19-108$ CI $562955^{*} 71158318554^{\mathrm{mg}}$.

${ }^{29} \mathrm{M}$ V L CI $242527562955^{*} 71245318554^{\mathrm{mg}}$

${ }^{30}$ Of the five manuscripts $\left(f=56-246 ; 55245707^{\mathrm{txt}}\right)$ some follow the B text, others might have suffered a haplography; 707 transmits the sentence in the margin.

${ }^{31}$ See my article "Was Samuel Meant to Be a Nazirite? The First Chapter of Samuel and the Paradigm Shift in Textual Study of the Hebrew Bible," Textus 28(2019): 1-20.
} 
It is interesting to compare two other cases in the same chapter in which the MT omits some details of the story.

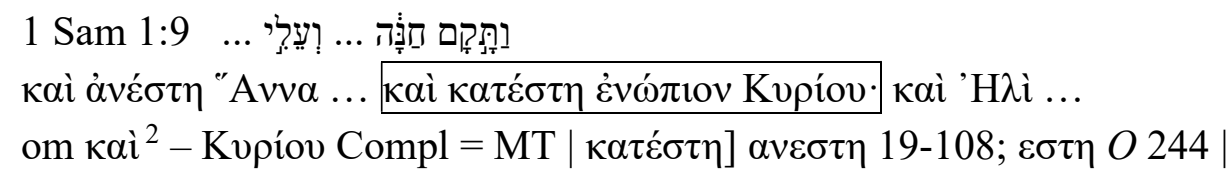

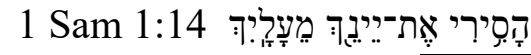

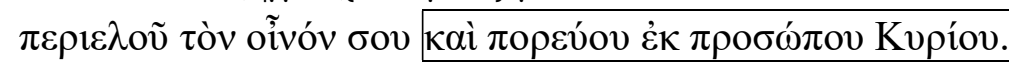

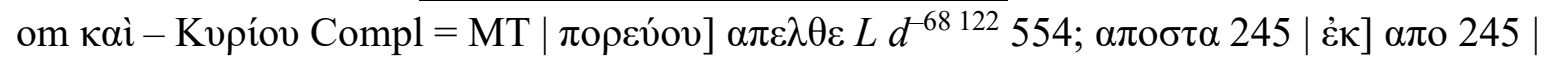

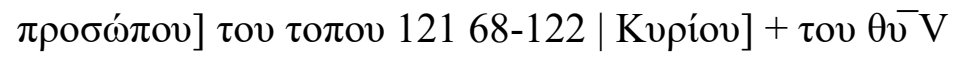

The omission of these sentences is found in none of the early witnesses, but only in the Complutensian polyglot, which reveals several such independent, late approximations to the MT. There are some scribal errors and minor variants in the wording, but these sentences were clearly considered to belong to the Septuagint.

According to his report, Origen used to mark such cases with an obelus, but none are preserved in these cases. Altogether very few obeli have been preserved. Later copyists could interpret an obelus as a sign for suspect details in the text, and thus as a permission to delete, but even where an obelus is preserved, omission is rare. The above-mentioned sentences were certainly seen to be essential for the story. However, it is impossible to judge whether these cases ever contained an obelus.

The different ways of dealing with the plusses of the Septuagint show that Origen did not compare the Greek text just with the Hebrew (or the Three reflecting it). If there were differences between the Greek manuscripts, he chose what was in harmony with the Three (and the Hebrew), and he could thus even omit such plusses, if they had been omitted before in one of his manuscripts.

Another interesting omission is found in the following example: ${ }^{32}$

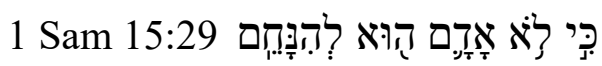

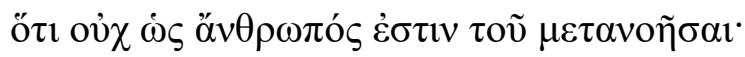

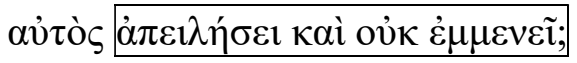

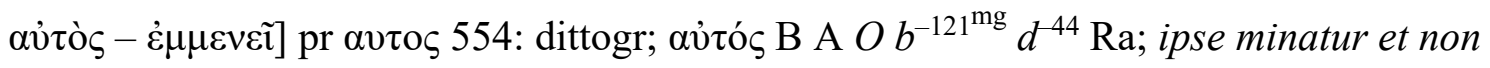

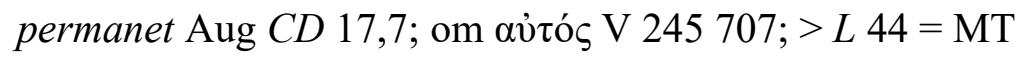

This is a very tricky case that I have discussed before as a case of pre-Hexaplaric, kaige-type approximation, in which the B text is followed by the Hexaplaric manuscripts (as well as the $d$ group). The shorter text of the verse (found also in Rahlfs's edition) ends with aủ co $_{\text {shich }}$ divulges the secondary nature of the shorter text, as this word is clearly a remnant of the omitted

\footnotetext{
${ }^{32}$ For a more thorough discussion, see my articles "A Kingdom at Stake: Reconstructing the Old Greek Deconstructing the Textus Receptus," in Scripture in Transition: Essays on Septuagint, Hebrew Bible, and Dead Sea Scrolls in Honour of Raija Sollamo, ed. A. Voitila and J. Jokiranta, JSJS 126 (Leiden: Brill, 2008), 353-366 (esp. 362364); and "Does God Regret? A Theological Problem that Concerned the Kaige Revisors," in The Legacy of Barthélemy: 50 Years after Les Devanciers d'Aquila, ed. Anneli Aejmelaeus and Tuukka Kauhanen, DSI 9 (Göttingen: Vandenhoeck \& Ruprecht, 2017), 41-53.
} 
sentence. ${ }^{33}$ Origen decides for the B text that is in harmony with the Hebrew text and leaves av่ ó in its place. Omission of just av่ ó $\varsigma$ by V 245707 and 44 (of $d$ group) as well the total omission of the sentence by $L$ might be due to the obscurity of the formulation. ${ }^{34}$ Origen's decision in this case is well in accord with the other examples we have seen and with his own principles.

A further example of a longer plus in the Septuagint is found at the end of the Song of Hannah:

\section{Sam 2:10}

Kúpios ä $\gamma 10 \varsigma$.

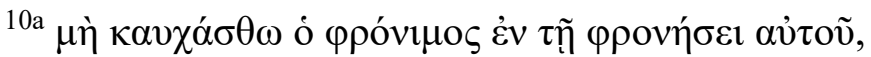

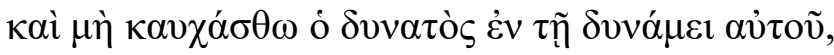

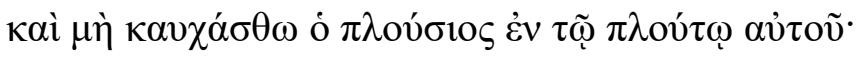

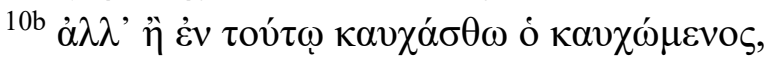

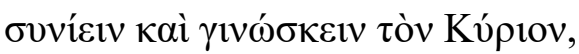

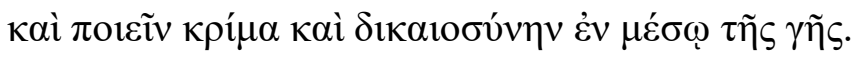

sub obelo M

The song of Hannah had a Vorlage that differed at some points from the MT. ${ }^{35} \mathrm{~V} .10$ shows a plus that - after Kúpıৎৎ ä $\gamma 10 \varsigma$ - parallels to Jer 9:22-23. ${ }^{36}$ One manuscript marks the passage with obelus, but there are no omissions. Obviously, the traditional text of the Septuagint was felt to be sacrosanct - not only by Origen but also by scribes after him - to such a degree that omissions according to the Hebrew text are rare. ${ }^{37}$

\section{Doublets}

There are numerous cases of a special type of plus in the Greek text of 1 Samuel, namely doublets (that is, the doubled translations of a word, a phrase, or a passage), which originated so early in the textual history that they are present in practically all the manuscripts. Nevertheless, they are not original, that is, just one half of the doublet is original. Which half is not always easy to tell. ${ }^{38}$ The secondary parts of such doublets originated with the earliest phase of revisional activity and comparison with the Hebrew text. The translation equivalents used in the secondary part are not

\footnotetext{
${ }^{33} \mathrm{Cf}$. the parallel structure of the passage in Bileam's oracle in Num 23:19.

${ }^{34}$ If $\alpha$ v่ ${ }^{5} \varsigma$ was marked by an obelus, this might have drawn the attention of the scribe behind $d$ to this case.

${ }^{35} \mathrm{Cf}$. also 4QSam ${ }^{\mathrm{a}}$ which partly agrees with the Septuagint; there is also a plus at the end of the psalm in 4QSam ${ }^{\mathrm{a}}$, but the manuscript is too fragmentary to allow any reconstruction in detail.

${ }^{36}$ For an exegesis of the passage, see my article "Hannah's Psalm in the Septuagint: Text, Translation, and Commentary," in 'Må de nu förklara...' Om bibeltexter, religion, litteratur: Festskrift för Staffan Olofsson, LIR. Skrifter (Gothenburg: Gothenburg University, 2018), 19-37.

${ }^{37}$ Reluctance to omit is perhaps also the reason why obeli are rarely transmitted. However, it is also worth noting that there are a few manuscripts - especially 44-107-125-610 of the $d$ group - that frequently remove redundancy. For

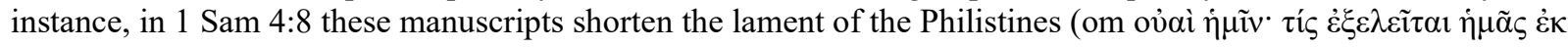
$\chi \varepsilon ı \rho ̀ \varsigma ~ \tau \tilde{\omega} v \theta \varepsilon \tilde{\omega} v \tau \tilde{\omega} v \sigma \tau \varepsilon \rho \varepsilon \tilde{\omega} v \tau o v ́ \tau \omega v ;$ 44-107-125-610). See also the omissions in 1 Sam 15:3 below.

${ }^{38}$ The doublets are also discussed by Brock, The Recensions of the Septuagint Version of 1 Samuel, 158-166. For a fairly extensive example, see my forthcoming article "Re-Linking Prophecy and Fulfilment in 1 Samuel 3 and 4," in Fortgeschriebenes Gotteswort: Studien zu Geschichte, Theologie und Auslegung des Alten Testaments (Tübingen: Mohr Siebeck, 2020).
} 
necessarily those preferred by the kaige revisers. ${ }^{39}$ However, it is often possible to discern in the more original part translation features that characterize the translator. In some cases, a change in the Hebrew text triggered the correction. This very early revision becomes visible only in the doublets. If there were other changes - for instance, plusses according to the proto-MT - that are present in the complete manuscript evidence, it is impossible to recognize them. ${ }^{40}$ The secondary part of a doublet must have been first added to the margin of a manuscript, and from there it was later moved into the text. This can be gathered from the different locations of these secondary readings, sometimes before the original reading, sometimes after it, and at times even at a false location.

When Origen was confronted with these readings, represented unanimously by all of his manuscripts, he would mark one half of the doublet with an obelus. But which part? Let us look at some examples.

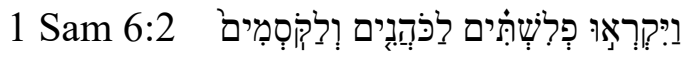

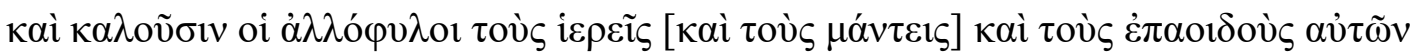

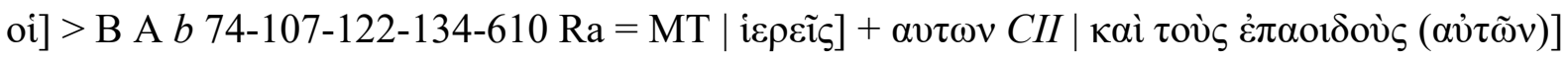
sub $\div 127 ;>$ Or Num 16,7: cf MT

The Greek text has two equivalents for the participle of the verb קסם (meaning 'a diviner').

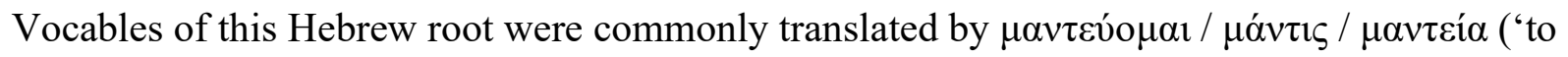
divine'/'a diviner'/'divination') in the Septuagint as well as by the Three. The second equivalent $\dot{\varepsilon} \pi \alpha o$ oó $\varsigma$ 'an enchanter' was however used for other Hebrew words, occurring even eight times in the Pentateuch. ${ }^{41}$ The latter was more probably the word picked up by the translator, and the former originated in an early correction that was first added to the margin of a manuscript and from their moved into the text. ${ }^{42}$ An obelus is transmitted by the Lucianic manuscript 127, marking the original translation as superfluous. In agreement with this, Origen in a quotation leaves out the second, original part of the doublet.

The following example is more complicated, showing an erroneous translation and several attempts at correction resulting in doublets:

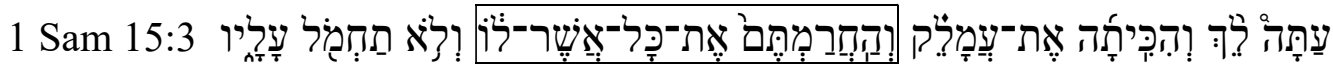

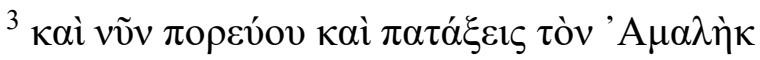

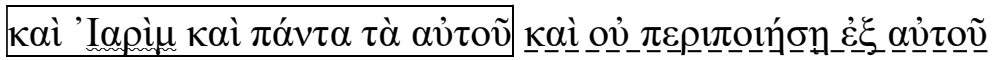

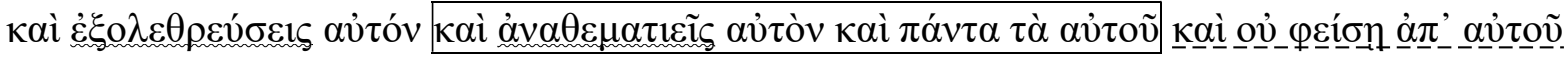
(Rahlfs)

\footnotetext{
${ }^{39}$ Similarly, already Brock, ibid., 158.

${ }^{40}$ For a possible example, see footnote 23 above.

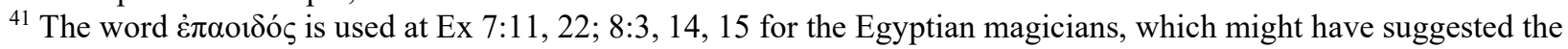
word for the translator of 1 Samuel, who was familiar with the vocabulary of the Greek Torah but not with the HebrewGreek equivalences used in it.

${ }^{42}$ Brock, The Recensions of the Septuagint Version of 1 Samuel, 160, also discusses 1 Sam 6:2 as a doublet. There is a faint possibility that the Vorlage had one more word (cf. 4QSam $\left.{ }^{a}\right)$, but this does not change the handling of the case by Origen.
} 


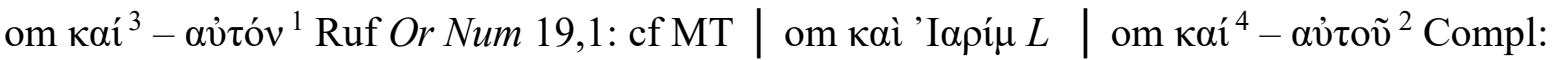

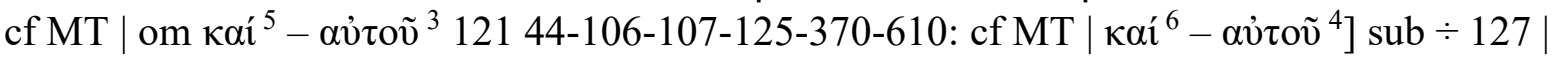
$\kappa \alpha i^{7} \frown{ }^{8}$ V 8274

In 1 Sam 15:3 the translator was confronted for the first time with the concept of (hif. "to devote to the ban'). He took it as a proper noun, which gave rise to several marginal corrections, resulting in doublets, partially triplets $(\dot{\varepsilon} \xi o \lambda \varepsilon \theta \rho \varepsilon v \dot{\sigma \varepsilon} \iota \varsigma$ and $\dot{\alpha} v \alpha \theta \varepsilon \mu \alpha \tau \iota \varepsilon \tilde{\iota} \varsigma$ being typical equivalents for the verb in question). The following sentence "do not spare them" was doubled too. The verb $\pi \varepsilon \rho \imath \pi 0 \imath \varepsilon \dot{o} \mu \alpha \imath$ 'to preserve,' 'to gain for oneself' was the equivalent used elsewhere by this translator. There is an obelus preserved in 127 marking the second, this time revisional part. There are also some omissions in the manuscripts, but not in accord with the obelus. What is interesting here is that Origen quotes this verse in his homily on Numbers (preserved in Rufinus's Latin translation), and leaves out the erroneous, original part quoting precisely according to the Hebrew

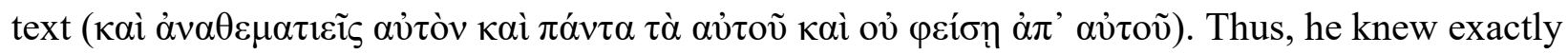
what the problem was in this verse, although he obviously did not try to correct the passage in his fifth column of the Hexapla.

The doublets must have been present in all manuscripts available to Origen, because otherwise he could have chosen a shorter alternative that agreed with the Hebrew (and the Three). Where an obelus is transmitted, it marks the latter part of the doublet or the part that differs from the order of the MT - whether original or secondary. A few later omissions do occur but not always according to the obelus.

\section{Asterisked Pluses}

Asterisked plusses, that is, complementation of those parts of the text that exist only in the Hebrew text, is probably the most well-known part of Origen's work. In the manuscript evidence, there is a great number of such complementations all over the text, ranging from single words and short phrases to sentences, verses, and longer passages. Chapters 17 and 18, in which the Hebrew text reveals a greatly expanded version of the story of David and Goliath and the beginning of David's career, provides plenty of examples.

There is great variation in the transmission of the asterisked plusses, in that none of the manuscript groups that transmit plusses contains all of them. ${ }^{43}$ At the other end of the spectrum is the B text that does not witness even one single asterisked plus. It is also interesting to see that several manuscripts that transmit the plusses do not follow the "healed" text of Origen's fifth column. This indicates that the plusses were excerpted from Hexaplaric sources - either directly from the Hexapla or from copies of the fifth column - while primarily copying a manuscript of another type. At the time when the plusses were adopted, the asterisks were obviously still in their place and helped to

\footnotetext{
${ }^{43}$ Brock, The Recensions of the Septuagint Version of 1 Samuel, 124. A similar observation concerning the whole Septuagint was already made by Soisalon-Soininen, Der Charakter der asterisierten Zusätze, 188-91, who plays with the thought that plusses lacking in the $O$ group might have been lacking in the $\theta^{\prime}$ column and could have been added later from the other columns. In 1 Samuel, where editorial activity on the Hebrew text continued especially long, this could very well have been the case.
} 
find the words and passages that needed to be complemented. The details "healed" by Origen, however, would not have drawn the attention of copyists. While excerpting the plusses, they also ignored several either by oversight or by choice. That these copyists would have left out the asterisks is also natural: after the plus was added, there was no need for an asterisk in a normal copy meant for ecclesiastic use. In catena manuscripts and study bibles, they were preserved longer, but it is not always clear which signs really originated with Origen, because similar signs could be used as indices for all kinds of marginal readings.

In the longer Hexaplaric plusses, there is often variation in the wording between the manuscript groups, which may have different reasons. There may have been scribal errors, but especially in the Lucianic text, there may also appear stylistic changes. Moreover, it is not clear which plusses really originated with Origen and which were perhaps added later on the basis of either the Hexapla or independent study of the Three. Especially in the case of the Lucianic recension, it seems that the revisers made independent use of Symmachus. This seems to have happened without reference to the Hebrew text on account of Greek texts only, which explains why the Lucianic text also produced doublets. Curiously enough, the different forms of the complementations sometimes seem to presuppose differences of the underlying Hebrew texts.

The following example is from the longer text of David and Goliath, from the beginning of the first long expansion.

\section{Sam 17:12 ודרוד

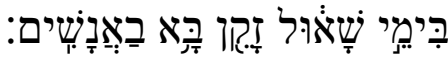
add A $O L C I C I I 509 d f s^{(-762)} 55158318554=$ MT (sub ※ 64-92( $\left.\left(\theta^{\prime} \lambda\right)\right)^{44}$

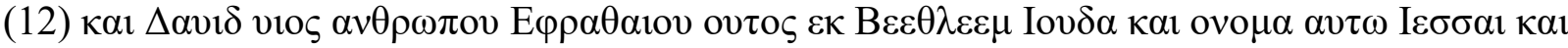

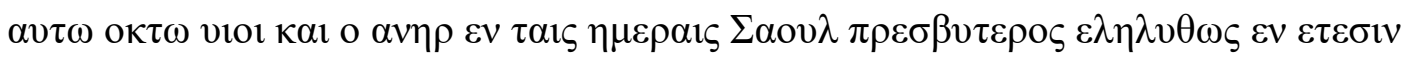

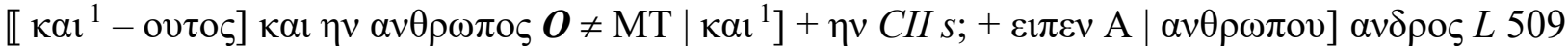

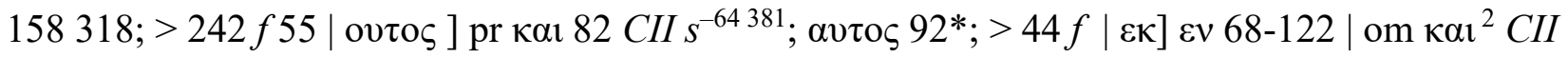

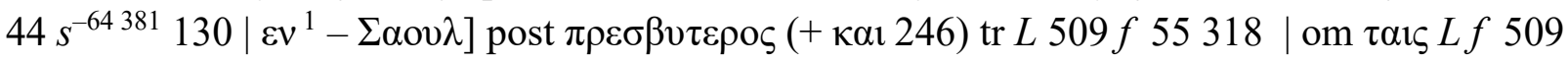

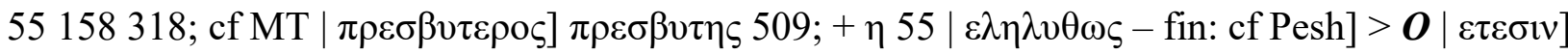
$\alpha v \delta \rho \alpha \sigma \mathrm{v}$ A $C I I s=\mathrm{MT} \rrbracket$

The Hexaplaric group $O$ represents a text-form in which it is David's father who is introduced in v. 12 in a formulation analogous to previous introductions of fathers of important characters (1 Sam $1: 1,9: 1),{ }^{45}$ whereas in the MT it is the young hero himself who is introduced. Jesse has been mentioned in chapter 16, but he has not been introduced anywhere else. The MT seems to represent the later tendency to glorify David. At the end of the verse, the curious phrase "advanced among men" (MT) is omitted by $O$ and translated literally in A $C I I s$, but the majority presupposes a

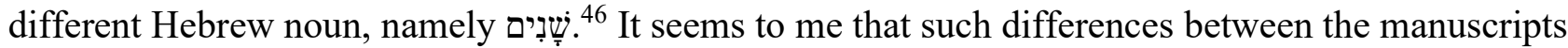
witnessing the complementations derive from different Hebrew texts. This means that editorial activity on the MT continued even after the expansion of 1 Sam 17-18 and that there may have

\footnotetext{
44 The complementation is not present in B V a 1212971244245460707.

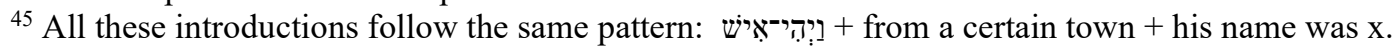

${ }^{46}$ The MT seems to be corrupted.
} 
been differences between the versions of the Three due to differences in their respective Vorlagen ${ }^{47}$ Approximation of the Greek text to the Hebrew may similarly have continued in the manuscripts after Origen. ${ }^{48}$

Let us consider another example from the complementations of the David and Goliath story:

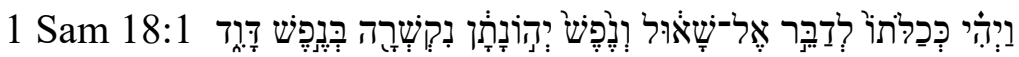

add (1-6) A $O$ L CI CII $d f s^{(-762)} 55158554=\mathrm{MT}^{49}$

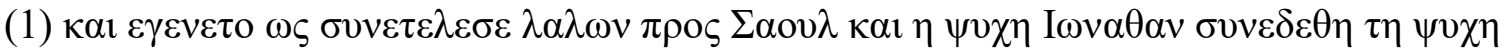
$\left.\Delta \alpha v 1 \delta \llbracket \kappa \alpha{ }^{1}-\omega \varsigma\right] \omega \varsigma \delta \varepsilon 44-125 ;+\varepsilon 1 \sigma \eta \lambda \theta \varepsilon(\eta \lambda \theta \varepsilon 554) \Delta \alpha v 1 \delta \pi \rho \circ \varsigma \Sigma \alpha o v \lambda \kappa \alpha 1 \boldsymbol{L} f$ $\left.\left.55158554^{\mathrm{mg}}(\neq \mathrm{MT}) \mid \sigma v v \varepsilon \tau \varepsilon \lambda \varepsilon \sigma \varepsilon-\pi \rho \circ\right] \varepsilon \sigma \tau \eta \delta \bar{\delta} \varepsilon v \omega \pi \iota v \boldsymbol{O}(\neq \mathrm{MT}) \mid \pi \rho{ } \Sigma \alpha \circ \nu \lambda\right] \alpha v \tau \omega \boldsymbol{L}$

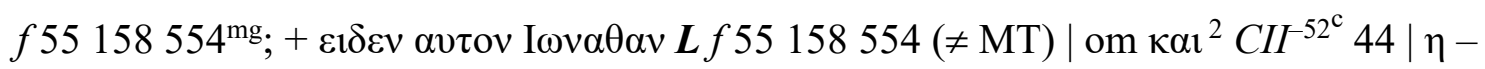

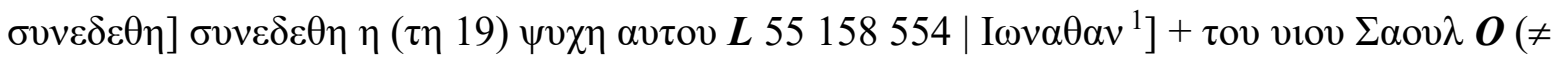
MT) 】

The different manuscript groups give different accounts of what happened after David's encounter with Goliath. According to the Hexaplaric group $O$, "it happened when David stood in front of Saul (that) the soul of Jonathan, Saul's son, was tied to David's soul." The Lucianic text offers a somewhat longer story: "It happened when David came to Saul and he finished talking to him (that is, Saul to David), Jonathan saw him, and his soul was tied to David's." The majority of the witnesses adding the passage follow the MT according to which David is the subject talking to Saul: "it happened when he finished talking to Saul (that) the soul of Jonathan..." Again, the simple account of $O$ makes the impression of being the original form of the complementation, based on a Hebrew text different from the MT. The Lucianic version agrees with $O$ in that it is the king speaking to the young hero and not the other way around. As for the other details, the Lucianic text seems to be based on another at least slightly different Hebrew text - perhaps through a later Greek translation - but some features might be due to the Lucianic recension as well. The form represented by the MT is evidently the latest update. The editorial reformulation that makes David the subject addressing the king is most probably connected to the later tendency of editors to glorify David.

\section{Readings of the Three}

Of the examples discussed so far, some included fragmentary readings of Aquila, Symmachus and Theodotion, which have been transmitted in commentaries by Church Fathers or as marginal notes in some manuscripts. These readings often reveal diverging translations (qualitative variants) that express the meaning of the Hebrew text more precisely, if the Old Greek rendering happens to be

\footnotetext{
${ }^{47}$ Soisalon-Soininen, Der Charakter der asterisierten Zusätze, 107, 190, 195, does not regard Origen as an independent reviser who would have worked directly on the Hebrew text. Thus, if he proceeded fairly mechanically on the basis of Theodotion, he would not necessarily have been aware of differences between the Three.

${ }^{48}$ Brock, The Recensions of the Septuagint Version of 1 Samuel, 172, presupposes a small number of post-Hexaplaric approximations.

${ }_{49}$ The complementation is not present in B V a b 2971244245318460707.
} 
free, contextual or simply false. Such readings were of course interesting to commentators. As far as they were attributed to the Three or any one of them, they had a certain guarantee to be correct explanations to the passage at hand. The attributions are, however, poorly and at times erroneously preserved. ${ }^{50}$ After the loss of the attributions, the function of the fragments of the Three as marginal readings cannot be distinguished from exegetical glosses that never had any attribution and were meant to explain rare or unusual expressions of the biblical text.

The following cases exemplify qualitative variants in a single or a few manuscripts that do or do not connect with readings of the Three, but are not based on Origen's fifth column:

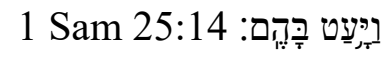

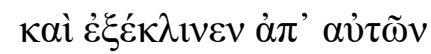

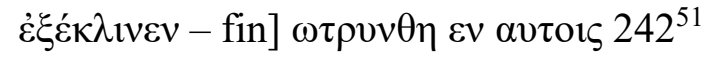

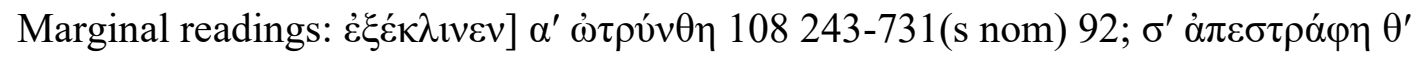

غ̇ं

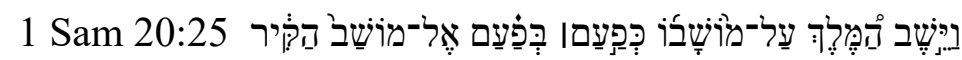

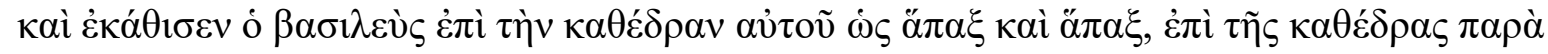

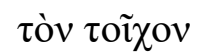

$\dot{\omega} \varsigma-\kappa \alpha \theta \varepsilon \dot{\delta} \rho \alpha \varsigma] \kappa \alpha \theta \omega \varsigma \varepsilon 1 \omega \theta \varepsilon \iota L^{52}$

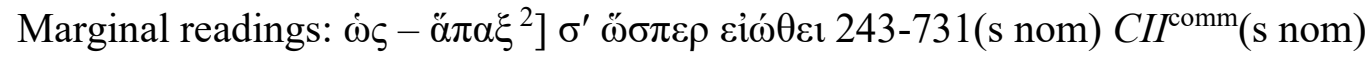

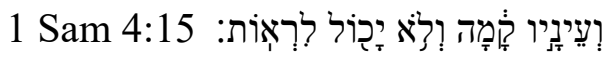

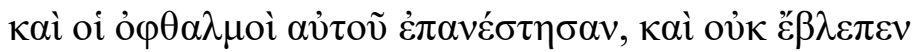

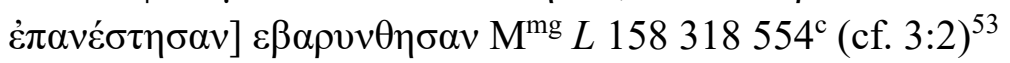

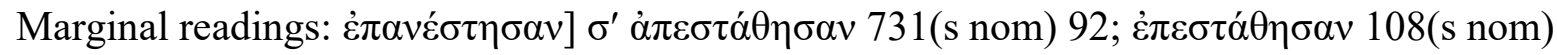

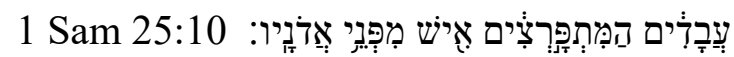

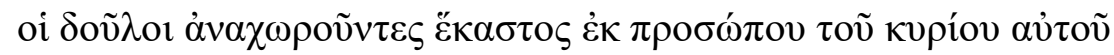

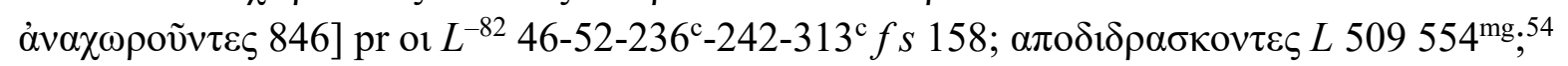

$\delta 1 \alpha \delta 1 \delta \rho \alpha \sigma \kappa о \nu \tau \varepsilon \varsigma 158$

Marginal readings: $\alpha \dot{v} \alpha \chi \omega \rho o \tilde{v} \tau \varepsilon \varsigma] \theta^{\prime} \dot{\alpha} \pi \circ \delta 1 \delta \rho \alpha ́ \sigma \kappa o v \tau \varepsilon \varsigma$ 243-731(s nom) 92

One of the catena groups functions as an illustration of what can have happened during textual transmission: of the $C I$ group, 243 is the oldest manuscript and it frequently preserves the attributions to the Three. The problem with this manuscript is, however, that it has lost the pages until 1 Sam 14:49. Manuscript 731 follows 243 in its marginal readings - being thus a potential aid in the reconstruction of the marginal readings - but 731 rarely gives the attributions! The latest manuscripts in the group are 98-379; in numerous cases, these manuscripts (at times along with 731) move the marginal readings into the text. The copyists simply did not understand the meaning

\footnotetext{
${ }^{50}$ For instance, manuscript 731 follows 243 in its marginal readings, but systematically almost everywhere leaves out the attributions (s nom) listing just three or two readings one after the other.

51 The catena manuscript 242 has adopted a reading from Aquila.

52 The Lucianic text has adopted a reading from Symmachus, which is witnessed by the attribution preserved in 243 , and at the same time, removed repetition.

${ }^{53}$ This variant is of Lucianic origin and is not based on the Hebrew text but rather on a parallel expression in the Greek text of 1 Sam 3:2.

${ }^{54}$ This variant is of Lucianic origin and based on either Theodotion or a kaige-type revisional text.
} 
of the attributions or the purpose of the marginal readings. Nevertheless, the marginal readings help to recognize the origin of these readings when they appear in the text of some manuscript or manuscript group. The following is an example of approximation to the Hebrew text which did not originate with the fifth column of the Hexapla.

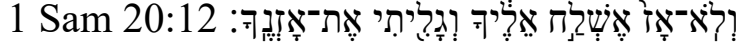

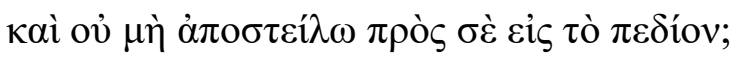

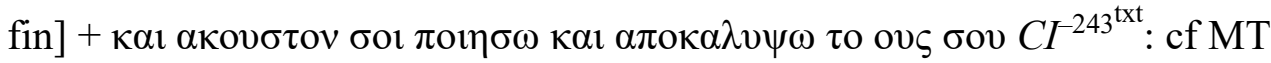

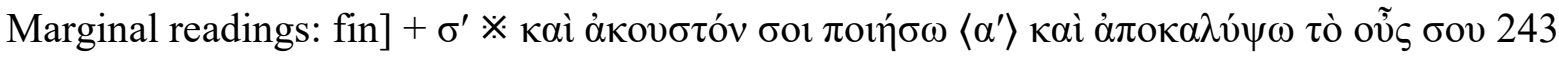

In this case, 243 gives an attribution to Symmachus but cites no doubt two different translations of the plus of the MT, the latter being a literal translation presumably from Aquila. ${ }^{55}$ The asterisk was used simply as an index or a sign for a plus. The two readings were included in the main text of the rest of manuscripts of the $C I$ group.

The following is an example from the complementations in 1 Sam 17-18.

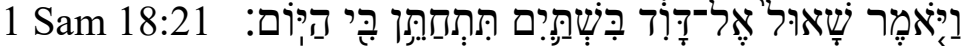

$$
\begin{aligned}
& \text { add (21) A } O L 379-731 C I^{-242} d 314554=\text { MT (sub ※ 127) }{ }^{56}
\end{aligned}
$$

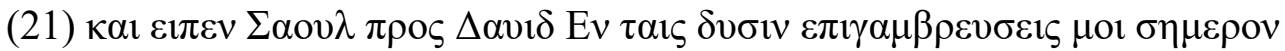

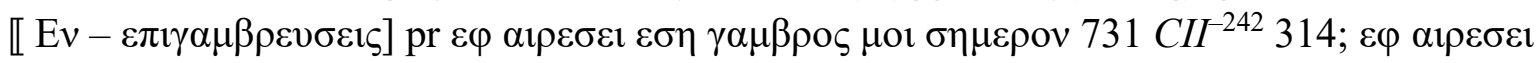

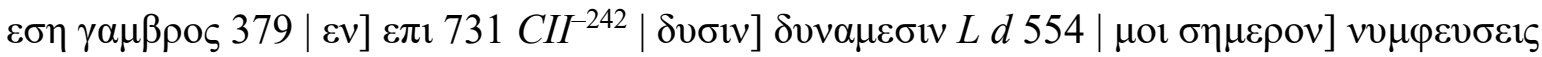
$\varepsilon v \varepsilon \mu \mathrm{or} 731 C I I^{-242} 314 \rrbracket$

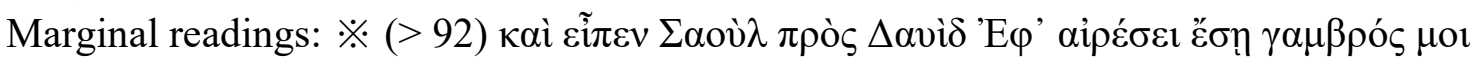

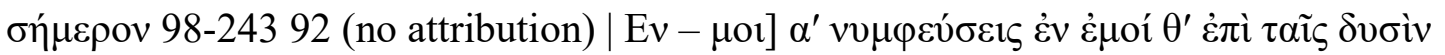
$\dot{\varepsilon} \pi \imath \alpha \mu \beta \rho \varepsilon v ́ \sigma \varepsilon 1 \varsigma 243554^{\mathrm{comm}}$

In this example, we can see three different ways of saying "you will become my son-in-law." Two

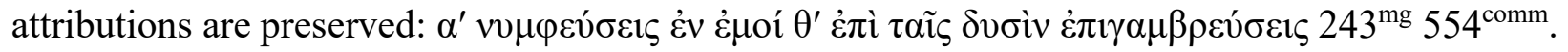

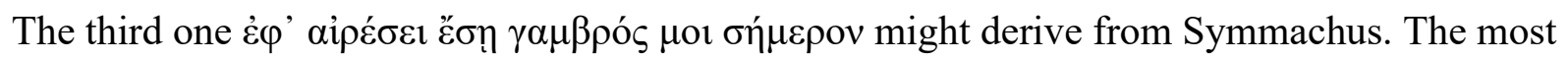
widely spread form is from Theodotion, but various manuscripts combine all three readings in their main text (731 CII ${ }^{242} 314$ ). Of the mentioned $C I$ group, 98-243 show the readings in question in their margins, whereas 379-731 have them in their main text: 731 depending on 243 shows all three alternative readings, 379 depending on 98 just one reading. All in all, what we see here is an asterisked plus that Origen adopted from Theodotion transmitted by A $O L d 554$. The catena manuscripts give the alternative readings of Aquila and possibly Symmachus, which are then combined with the reading of the fifth column.

The designation Hexaplaric is also applied to the readings that are collected in the second apparatus of the Göttingen critical edition, called the Hexaplaric apparatus. A great deal of this material certainly came to the attention of Christian writers and copyists through the Hexapla. However, the

\footnotetext{
55 The plus of the MT is reflection from the following v. 13 and obviously of late origin. Transmitted only by the $C I$ group, the Greek plus was perhaps not yet present in Theodotion.

${ }^{56}$ The complementation is not present in B V $845242 a b f s^{-92^{\mathrm{mg}}} 295571158244245318460707$.
} 
infiltration of these readings into the manuscript tradition no longer corresponds to Origen's principles, as we can see from the above examples. It is also an open question as to how much of this material really stems from the Hexapla and how much is based on other sources, for instance, Patristic commentaries, or perhaps on an independent study of the Three as long as there were copies of them available. ${ }^{57}$ In the case of the Lucianic recension which frequently adopts readings of Symmachus, one could imagine that this translation was consulted from a separate copy, not just marginal readings.

\section{To Conclude}

Many things about the origins of the Hexaplaric recension remain in darkness. However, going through the Greek manuscript evidence for a book like, for instance, 1 Samuel, it is easy to see the repercussions of the activities of Origen and his followers. Unlike the readings resulting from Origen's "healing" procedure, the asterisked plusses are not confined to one manuscript group only but are distributed in different manuscripts and manuscript groups. The Aristarchian signs are seldom preserved, but the nature of these readings is revealed by comparison with the Hebrew text. In addition to the Hexaplaric recension based on the fifth column of the Hexapla there are also other readings that were of Hexaplaric origin but not part of the Hexaplaric recension as well as preHexaplaric Hebraizing readings that may coincide with readings recorded in the Hexapla. Thus, Origen had his predecessors, who compared the text of the Septuagint directly with their contemporary Hebrew text, whereas later scholars, for instance, Patristic writers in their commentaries of the biblical text, followed Origen in using the Three for comparison and for clarification. However, since the later generations consulted the Three without the Hebrew text, they at times happened to produce doublets or even triplets. In a way, they followed Origen's example but clearly had different goals and principles in their exegetical work. Thus, it is essential to distinguish between the later work of the commentators and Origen's text-critical work.

\section{Bibliography}

Anneli Aejmelaeus, "David's Return to Ziklag: A Problem of Textual History in 1 Sam 30:1," in XII Congress of the International Organization for Septuagint and Cognate Studies, Leiden 2004, ed. M. Peters. SCS 54 (Leiden/Boston: Brill, 2006), 95-104.

Aejmelaeus, Anneli, "A Kingdom at Stake: Reconstructing the Old Greek - Deconstructing the Textus Receptus," in Scripture in Transition: Essays on Septuagint, Hebrew Bible, and Dead Sea Scrolls in Honour of Raija Sollamo, ed. A. Voitila and J. Jokiranta, JSJSup 126 (Leiden: Brill, 2008), 353-366.

\footnotetext{
${ }^{57}$ Reinhart Ceulemans, “Greek Christian Access to 'The Three', 250-600 CE,” in Greek Scripture and the Rabbis, ed. Timothy Michael Law and Alison Salvesen, CBET 66 (Leuven: Peeters, 2012), 165-191, argues that, as a rule, readings of the Three in Christian texts and manuscripts were taken from a source that eventually reaches back to the Hexapla and not directly from manuscripts of the Three. Ceulemans does not, however, discuss the case of the Lucianic recension.
} 
Aejmelaeus, Anneli, "Textual History of the Septuagint and the Principles of Critical Editing," in The Text of the Hebrew Bible and Its Editions: Studies in Celebration of the Fifth Centennial of the Complutensian Polyglot, ed. Andrés Piquer Otero \& Pablo Torijano Morales.

Supplements to the Textual History of the Bible 1 (Leiden/Boston: Brill, 2016), 160-179.

Aejmelaeus, Anneli, "Kaige Readings in a Non-Kaige Section in 1 Samuel," in The Legacy of Barthélemy: 50 Years after Les Devanciers d'Aquila, ed. Anneli Aejmelaeus and Tuukka Kauhanen: DSI 9 (Göttingen: Vandenhoeck \& Ruprecht, 2017), 169-184.

Aejmelaeus, Anneli, "Does God Regret? A Theological Problem that Concerned the Kaige Revisers," in The Legacy of Barthélemy: 50 Years after Les Devanciers d'Aquila, ed. Anneli Aejmelaeus and Tuukka Kauhanen. DSI 9 (Göttingen: Vandenhoeck \& Ruprecht, 2017), 4153.

Aejmelaeus, Anneli, "Hannah's Psalm in the Septuagint: Text, Translation, and Commentary," in 'Må de nu förklara...' Om bibeltexter, religion, litteratur: Festskrift för Staffan Olofsson. LIR.Skrifter (Gothenburg: Gothenburg University, 2018), 19-37.

Aejmelaeus, Anneli, "Was Samuel Meant to Be a Nazirite? The First Chapter of Samuel and the Paradigm Shift in Textual Study of the Hebrew Bible," Textus 28 (2019): 1-20.

Aejmelaeus, Anneli, "The Origins of the Kaige Revision," in Scriptures in the Making: Texts and Their Transmission in Late Second Temple Judaism, ed. Raimo Hakola, Paavo Huotari and Jessi Orpana, CBET (Leuven: Peeters, 2020), forthcoming.

Aejmelaeus, Anneli, "Re-Linking Prophecy and Fulfilment in 1 Samuel 3 and 4," in Fortgeschriebenes Gotteswort: Studien zu Geschichte, Theologie und Auslegung des Alten Testaments (Tübingen: Mohr Siebeck, 2020), forthcoming.

Barthélemy, Dominique, Les devanciers d'Aquila, VTSup X (Leiden: Brill, 1963).

Brock, Sebastian P., The Recensions of the Septuagint Version of 1 Samuel (Ph.D. dissertation, Oxford 1966). Quaderni di Henoch 9, Foreword by Natalio Fernández Marcos (Torino: Silvio Zamorani, 1996).

Ceulemans, Reinhart, "Greek Christian Access to 'The Three', 250-600 CE," in Greek Scripture and the Rabbis, ed. Timothy Michael Law and Alison Salvesen. CBET 66 (Leuven: Peeters, 2012), 165-191.

Driver, S. R., Notes on the Hebrew Text and the Topography of the Books of Samuel. $2^{\text {nd }}$ edition, revised and enlarged (Oxford: Clarendon, 1913).

Fernández Marcos, Natalio, The Septuagint in Context: Introduction to the Greek Versions of the Bible (Boston/Leiden: Brill, 2001).

Frederick Field's Prolegomena to Origenis Hexaplorum quae supersunt, sive veterum interpretum graecorum in totum Vetus Testamentum fragmenta, Translated and annotated by Gérard J. Norton O.P., with the collaboration of Carmen Hardin. Cahiers de la Revue Biblique 62 (Paris: J. Gabalda, 2005). 
Jellicoe, Sidney, The Septuagint and Modern Study (Oxford: Clarendon, 1968).

Johnson, Bo, Die hexaplarische Rezension des 1. Samuelbuches der Septuaginta, Studia Theologica Lundensia 22 (Lund: Gleerup, 1963).

Kharanauli, Anna, "Origen and Lucian in the Light of Ancient Editorial Techniques," in From Scribal Error to Rewriting: How Ancient Texts Could and Could Not Be Changed, ed. Anneli Aejmelaeus, Drew Longacre \& Natia Mirotadze. DSI 12 (Göttingen: Vandenhoeck \& Ruprecht, 2020).

Neuschäfer, Bernhard, Origenes als Philologe, I-II, Schweizeriche Beiträge zur Altertumswissenschaft 18/1-2 (Basel: Friedrich Reinhardt Verlag,1987).

Rahlfs, Alfred, Septuaginta-Studien I - III. 2. Auflage, Vermehrt um einen unveröffentlichten Aufsatz und eine Bibliographie, mit einem Nachruf von Walter Bauer (Göttingen: Vandenhoeck \& Ruprecht, 1965).

Salvesen, Alison, "A Convergence of the Ways? The Judaizing of Christian Scripture by Origen and Jerome," in The Ways that Never Parted: Jews and Christians in Late Antiquity and the Early Middle Ages, ed. Adam H. Becker and Annette Yoshiko Reed. Texte und Studien zum antiken Judentum 95 (Tübingen: Mohr Siebeck, 2003), 233-258.

Schaper, Joachim, "The Origin and Purpose of the Fifth Column of the Hexapla," in Origen's Hexapla and Fragments: Papers Presented at the Rich Seminar on the Hexapla, Oxford Centre for Hebrew and Jewish Studies $25^{\text {th }}$ July - $3^{\text {rd }}$ August 1994, ed. Alison Salvesen, Texte und Studien zum Antiken Judentum 58 (Tübingen: Mohr Siebeck, 1998), 3-15.

Soisalon-Soininen, Ilmari, Der Charakter der asterisierten Zusätze in der Septuaginta. AASF B 114 (Helsinki: Suomalainen tiedeakatemia, 1959).

Swete, Henry Barclay, An Introduction to the Old Testament in Greek. $2^{\text {nd }}$ edition (Cambridge: University Press, 1914).

Thackeray, Henry St. John, "The Greek Translation of the Four Books of Kings," JTS 8 (1907): $262-78$.

Wevers, John William, Notes on the Greek Text of Deuteronomy. SCS 39 (Atlanta, GA: Scholars Press, 1995).

Wirth, Raimund, "Dealing with Tenses in the Kaige Section of Samuel," in The Legacy of Barthélemy: 50 Years after Les Devanciers d'Aquila, ed. A. Aejmelaeus \& T. Kauhanen. DSI 9 (Göttingen: Vandenhoeck \& Ruprecht, 2017), 185-197. 